\title{
Perlindungan Hukum Terhadap Hak-Hak Narapidana Di Lembaga Pemasyarakatan Kelas IIB Ngawi
}

\author{
Kantrey Sugiarto $^{1}$, R. Kurniawan Bagus Wicaksono ${ }^{2}$, Sumiati $^{3}$, Sangrila Puspita Dewi ${ }^{4}$

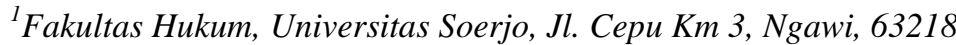 \\ E-mail: kantrey23@gmail.com \\ ${ }^{2}$ Fakultas Hukum, Universitas Soerjo, Jl. Cерu Km 3, Ngawi, 63218 \\ E-mail: kurniawan.fh00@gmail.com \\ ${ }^{3}$ Fakultas Ilmu Sosial dan Ilmu Politik, Universitas Soerjo, Jl. Cepu Km 3, Ngawi, 63218 \\ E-mail: Sumiaty688@gmail.com \\ ${ }^{4}$ Fakultas Ilmu Sosial dan Ilmu Politik, Universitas Soerjo, Jl. Cepu Km 3, Ngawi, 63218 \\ E-mail: sangrilapuspita92@gmail.com
}

\begin{abstract}
Prisoners who are placed in prison are sometimes considered to have no rights whatsoever. They are sometimes treated inhumanely because they are considered to have committed a mistake or a crime so that their actions must be repaid in prison. The method used in this paper is normative juridical, which is research that is focused on studying the norms or norms in positive law which are then used as legal material to conduct research in Class II B Ngawi Prison regarding the rights of prisoners there. The efforts made by Ngawi Prison in the context of fulfilling the rights of prisoners have referred to the provisions of the applicable laws and regulations. In an effort to fulfill the rights of prisoners, it was found that there were obstacles faced due to the overcapacity of the inhabitants of the Ngawi Prison. With the results of this research, the main potential in the future is that it can be used as reference material for future prisoners, as a reference for further research with the development of the theme of over capacity, and as a bridge of information to overcome the gap between life in prison and the outside world.
\end{abstract}

Keywords_—: Prisoners; Rights; Protection.

\section{PENDAHULUAN}

\section{A. Latar Belakang}

Pembinaan di LP menekankan konsep rehabilitasi dan reintegrasi sosial yang bertujuan untuk menjadikan Narapidana dapat diterima kembali oleh masyarakat dan tidak lagi mengulangi kesalahan yang dilakukannya. Dalam Pasal 2 UU Pemasyarakatan, menyatakan bahwa :

"Sistem pemasyarakatan diselenggarakan dalam rangka membentuk Warga Binaan Pemasyarakatan agar menjadi manusia seutuhnya, menyadari kesalahan, memperbaiki diri, dan tidak mengulangi tindak pidana sehingga dapat diterima kembali oleh lingkungan masyarakat, dapat aktif berperan dalam pembangunan, dan dapat hidup secara wajar sebagai warga yang baik dan bertanggung jawab." 1

Narapidana yang yang ditempatkan LP terkadang dianggap tidak mempunyai hak apapun. Mereka terkadang diperlakukan secara tidak manusiawi karena dianggap telah melakukan suatu kesalahan ataupun kejahatan sehingga perbuatan mereka harus dibalas di LP. Hal ini bisa menimbulkan penderitaan fisik dan juga penderitaan psikis, karena mereka kehilangan kemerdekaannya dalam bergerak serta kehilangan hak-hak dasar sebagai manusia (Hak Asasi Manusia).

LP Kelas II B Ngawi yang beralamat di jalan Thamrin No. 35 Ngawi merupakan salah satu Unit Pelaksana Teknis divisi kemasyarakatan dibawah Direktorat Jendral Pemasyarakatan Kementerian Hukum dan HAM yang dalam pelaksanaan tugas dan fungsinya tunduk kepada regulasi UU Pemasyarakatan dan

PP Pelaksanaan Hak Warga Binaan Pemasyarakatan. Untuk memahami lebih lanjut terkait pemenuhan hak-hak narapidana di LP yang tersebut di atas, diperlukan adanya penelitian yang akan dilakukan sesuai dengan karakteristik ilmu hukum sebagai ilmu yang bersifat preskriptif dan terapan dengan judul "Perlindungan Hukum Terhadap Hak-Hak Narapidana Di Lembaga Pemasyarakatan Kelas II B Ngawi”.

\section{B. Rumusan Masalah}

1. Apa yang dilakukan LP Kelas II B Ngawi dalam memenuhi hak-hak narapidana yang di binanya?

2. Apa kendala yang di hadapi dalam pemenuhan hak-hak narapidana yang di binannya?

\footnotetext{
${ }^{1}$ Undang-Undang Nomor 12 Tahun 1995 tentang Pemasyarakatan (Lembar Negara Tahun 1981 Nomor 76, Tambahan Lembar Negara Nomor 3641);
} 
Website : http://yustisia.unmermadiun.ac.id/index.php/yustisia

\section{Tujuan dari kegiatan}

1. Untuk mengetahui yang dilakukan LP Kelas II B Ngawi dalam memenuhi hak-hak narapidana yang di binanya.

2. Untuk mengetahui kendala yang di hadapi dalam pemenuhan hak-hak narapidana yang di binannya.

\section{Manfaat}

1. Upaya profesi Dosen sebagai peneliti yang mandiri, jujur, dan bertanggung jawab sesuai kaidah dan norma akademis sehingga dapat turut serta menyebarluaskan ilmu pengetahuan dengan tepat di masyarakat.

2. Membangun jejaring antara Fakultas Hukum sebagai lembaga pendidikan dengan LP Kelas II B Ngawi sebagai salah satu stakeholder. Dengan jejaring yang semakin baik, ke depan akan mampu menunjang kegiatan Tri Dharma PT lainnya.

\section{METODE}

Tipe penelitian yang dipakai dalam penelitian ini adalah yuridis normatif, yaitu penelitian yang difokuskan untuk mengkaji kaidah-kaidah atau norma-norma dalam hukum positif yang kemudian dijadikan bahan hukum untuk melakukan penelitian di LP kelas II B Ngawi terkait hak-hak narapidana di sana. Tipe penelitian yuridis normatif tidak dimulai dari suatu hipotesis, tetapi penelitian ini berangkat dari pengidentifikasian fakta hukum dan mengeleminir hal-hal yang tidak relevan untuk selanjutnya ditetapkan sebagi isu hukum yang hendak dipecahkan. Hal ini seperti yang diungkapkan Peter Mahmud Marzuki yang berpendapat sebagai berikut "Oleh karena secara karakteristik berbeda antara keilmuan hukum dan keilmuan yang bersifat diskriptif tersebut, penelitian hukum tidak perlu dimulai dengan hipotesis. Dengan demikian istilah variabel bebas dan variabel terikat tidak dikenal dalam penelitian hukum." 2

\section{III.HASIL DAN PEMBAHASAN}

\section{A. Upaya Lembaga Pemasyarakatan Kelas II B Ngawi dalam memenuhi hak-hak narapidana yang di binanya}

Lembaga Pemasyarakatan Kelas IIB Ngawi (selanjutnya di sebut Lapas Ngawi) terletak di pusat kota Kabupaten Ngawi Provinsi Jawa Timur. Lapas yang bersebelahan tepat dengan alun-alun kabupaten ini memiliki daya tampung sebesar 200 orang. Daya tampung tersebut ditempati oleh Tahanan dan Narapidana baik laki-laki maupun perempuan, dan dewasa maupun anakanak. Mengacu pada Informasi dan data yang dipublikasikan oleh Direktorat Jenderal Pemasyarakatan (Ditjen PAS) Kementrian Hukum \& HAM yang sumber datanya disuplai langsung oleh Unit Pelaksana Teknis Lapas Ngawi, pada bulan juni 2019 penghuni lapas ini berjumlah 374 yang terdiri dari:

\begin{tabular}{|l|l|l|l|}
\hline Tahanan & Jml & Narapidana & Jml \\
\hline $\begin{array}{l}\text { Dewasa Laki- } \\
\text { Laki }\end{array}$ & 39 & $\begin{array}{l}\text { Dewasa Laki- } \\
\text { Laki }\end{array}$ & 323 \\
\hline $\begin{array}{l}\text { Dewasa } \\
\text { Perempuan }\end{array}$ & 2 & $\begin{array}{l}\text { Dewasa } \\
\text { Perempuan }\end{array}$ & 10 \\
\hline $\begin{array}{l}\text { Anak Laki- } \\
\text { Laki }\end{array}$ & 0 & $\begin{array}{l}\text { Anak Laki- } \\
\text { Laki }\end{array}$ & 0 \\
\hline $\begin{array}{l}\text { Anak } \\
\text { Perempuan }\end{array}$ & 0 & $\begin{array}{l}\text { Anak } \\
\text { Perempuan }\end{array}$ & 0 \\
\hline Sub Total & 41 & Sub Total & 333 \\
\hline \multicolumn{3}{|c|}{ Total : 374 (kelebihan 187 orang/87\% } \\
dari daya tampung) \\
\hline
\end{tabular}

Dari jumlah tersebut di atas, sebanyak 333 orang narapidana terikat dengan Undang-Undang Nomor 12 Tahun 1995 tentang Pemasyarakatan Pasal 14 ayat (1) terkait dengan hak narapidana. Dalam rangka memenuhi ketentuan regulasi tersebut, adapun yang dilakukan Lapas Ngawi adalah sebagai berikut:

\section{Hak beribadah;}

Narapidana yang beragama Islam dapat menjalankan kewajibannya di masjid yang terletak di komplek area lapas. Pihak lapas juga memfasilitasi kegiatan mengaji dan siraman rohani setiap lepas sholat subuh. Khusus untuk hari kamis ada tambahan acara pengajian rutin bekerjasama dengan pondok pesantren temboro kabupaten Ngawi. Untuk narapidana yang beragama Kristen dan Katolik, pada hari minggu dilakukan acara keagaman kebaktian dengan mendatangkan

\footnotetext{
${ }^{2}$ Peter Mahmud Marzuki, Penelitian Hukum, Kencana, Jakarta, cetakan ke-6, Februari 2010.hal 35.

${ }^{3}$ http://smslap.ditjenpas.go.id/ di akses pada 8 Juli 2019 pukul 18.30 WIB
} 
pendeta dari gereja setempat. Dengan kegiatan seperti ini diharapkan mampu memupuk rasa iman narapidana kepada agamanya masing-masing.

\section{Hak mendapat perawatan;}

Perawatan yang diberikan oleh pihak Lapas Ngawi kepada narapidana yang dibina berupa perawatan jasmani dan rohani. Hal ini diberikan dalam rangka menjaga kondisi fisik dan mental narapidana tetap terjaga, karena kehidupan didalam lapas bagi seorang narapidana sangat jauh berbeda dibanding sebelumnya. Terlebih lagi, untuk penghuni baru, sering mengalami gejala stres. Perawatan jasmani secara rutin dilakukan pada hari jumat dengan melakukan senam pagi bersama, serta memberikan asupan makanan yang sesuai dengan ketentuan yang berlaku. Selanjutnya, terkait perawatan rohani salah satunya ada melakukan pelayanan kunjungan keluarga/tamu narapidana dengan baik sesuai dengan ketentuan yang berlaku. Hal ini dilakukan dengan menyiapkan tempat kunjungan yang luas dengan sirkulasi udara cukup, sehingga ketika narapidana bertemu dengan keluargannya terasa nyaman. Kegiatan-kegiatan tersebut di atas diharapkan dapat menunjang kekuatan lahir dan batin narapidana selama beradadilingkungan Lapas Ngawi.

\section{Hak dalam pendidikan dan pengajaran;}

Lapas Ngawi bekerjasama dengan pihak terkait memberikan fasilitas kejar Paket A, B, dan C untuk narapidana yang terputus/belum sekolah. Dengan program ini, diharapkan setelah narapidana menyelesaikan masa hukumannya dapat menggunakan ijazah dari program pendidikan tersebut untuk memperoleh pekerjaan yang lebih baik dari sebelumnya. Dalam hal pengajaran atau biasa yang disebut keterampilan, Lapas Ngawi membekali warga yang dibinanya dengan keterampilan membuat boneka, bantal, dan aneka pernak-pernik yang biasanya ditampilkan di ekspo alun-alun kabupaten Ngawi. Ada pula program pelatihan komputer yang setiap satu kali diadakan ujian.

4. Hak mendapatkan pelayanan kesehatan dan makanan yang layak;

Setiap satu tahun sekali, diadakan penyuluhan kesehatan yang bekerjasama dengan Dinas Kesehatan Kabupaten Ngawi. Di dalam juga terdapat klinik kesehatan sebagai fasilitas kesehatan pertama untuk warga binaan. Untuk narapidana yang sakit dan tidak bisa ditangani di klinik lapas, maka pasien tersebut akan dirujuk ke RSUD umum setempat dengan pengawalan dan prosedur yang ada.

\section{Hak menyampaikan keluhan;}

Kehidupan di dalam Lapas Ngawi tidak terlepas seperti kehidupan dalam bermasyarakat pada umumnya. Ketidak cocokan antar pengelola dengan penghuni atau antar sesama narapidana pun tidak bisa dihindari. Dalam upaya meminimalisir hal tersebut serta untuk menjaga iklim tetap kondusif, pihak Lapas Ngawi mempunyai unit khusus yang menangani serta menampung keluhan-keluhan dari warga binaan. Upaya ini sangat efektif dalam rangka menjaga kerukunan dan menyambung informasi dalam kehidupan di Lapas Ngawi.

6. Hak mendapatkan bahan bacaan dan mengikuti siaran media massa lainnya yang tidak dilarang;

Disediakan ruang baca/perpustakaan di dalam lapas yang diperuntukan untuk seluruh warga binaan. Terdapat koleksi buku keagamaan, sosial, dan sejarah yang cukup untuk menambah wawasan warga binaan. Pengelola perpus pun mengijinkan dengan batasan waktu tertentu apabila warga binaan ingin meminjam buku tersebut untuk dibawa dikamar selnya. Untuk mengikuti perkembangan dunia di luar lapas, disediakan pula media cetak berupa koran, yang bisa dibaca oleh warga binaan setiap harinya.

7. Hak mendapatkan upah atau premi atas pekerjaan yang dilakukan;

Narapidana yang ikut dalam program ketrampilan, dari setiap produk yang layak dipasarkan, akan mendapat upah dari keryanya tersebut. Kegiatan ini dikelola oleh koperasi Lapas Ngawi.

8. Hak menerima kunjungan keluarga, penasihat hukum, atau orang tertentulainnya;

Setiap hari senin-kamis setiap meinggunya, narapidana berhak menerima kunjungan dari keluarga, penasihat hukum, atau tamu lainnya. Disediakan tempat yang representatif dalam menerima kunjungan. Setiap pengunjung sebelum menemui narapidana diperiksa barang bawaanya. Narkoba, benda tajam berbahaya, bahan yang mudah meledak, dan lainnya menurut aturan perundang-undangan dilarang di bawa waktu kunjungan selalu diperiksa dengan teliti dan akan disita oleh petugas apabila ditemukan hal-hal tersebut. Khusus untuk kunjungan narapidana anak diperkenenkan pada hari sabtu.

\section{Hak pengurangan masa pidana (remisi), cuti mengunjungi keluarga, dan pembebasan bersyarat;}

Hak tersebut di atas diberikan pada narapidana yang sesuai ketentuan perundang-undangan berperilaku baik dan tidak berisiko untuk menyalahgunakan hak yang diberikan. khusus untuk hak cuti mengunjungi keluarga selama ini hampir tidak ada yang mengambilnya. Syarat yang ketat berdasar Standar Operasional Pelaksanaan membuat hak ini jarang digunakan oleh narapidana. Hal ini wajar karena resiko narapidana melarikan diri sangat besar. Namun apabila ada 
Website : http://yustisia.unmermadiun.ac.id/index.php/yustisia

narapidana yang akan menggunakan hak tersebut, tetaplah dilayani dengan catatan memenuhi persyaratan sesuai ketentuan yang ada.

10. Hak lain sesuai dengan peraturan perundang- undangan yang berlaku;

Hak yang dimaksud disini salah satunya adalah hak untuk menentukan pilihan politiknya, sepanjang hak tersebut tidak dicabut oleh hakim yang memutus perkaranya. Lapas Ngawi bekerjasama dengan pihak terkait (KPUD Ngawi dan Panitia Pemilihan Kepala Desa di Ngawi) untuk memberikan pelayanan menyalurkan hak narapidana.

\section{B. Kendala yang di hadapi dalam pemenuhan hak-hak narapidana yang di bina di Lembaga Pemasyarakatan Kelas II B Ngawi}

Bertitik tolak dari Tabel 1. Jumlah penghuni Lapas Ngawi pada bulan Juni 2019 di atas, ada suatu sajian yang menarik terkait jumlah penghuni Lapas Ngawi. Dari kapasitas 200 orang, pada bulan juni 2019 terdapat kelebihan daya tampung sejumlah 187 orang atau 87\% dari standar kapasitas. Keadaan seperti ini tidak hanya terjadi pada bulan juni 2019 saja, tapi juga terjadi di bulan-bulan sebelumnya yang secara rinci tersaji dalam tabel berikut ini: ${ }^{4}$

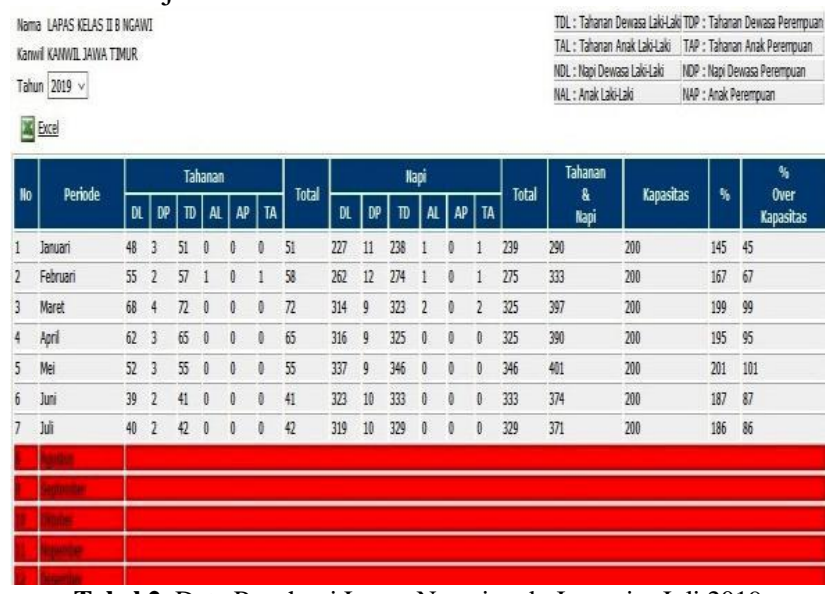

Tabel 2. Data Penghuni Lapas Ngawi pada Januari - Juli 2019

Prosentase kelebihan daya tampung penghuni Lapas Ngawi (Tahanan dan Narapidana) dapat terlihat pada tabel di atas di sisi kolom paling kanan. Puncak kenaikan terjadi pada bulan mei 2019 yang mencapai lebih dari 100\%. Kemudian pada bulan juni dan juli 2019 mengalami penurunan meski tidak seberapa yang berkisar turun $18 \%$. Jika dilihat lebih khusus terkait jumlah narapidana yang terletak pada kolom 5 dari kanan juga tidak pernah di bawah angka 200 pada bulan-bulan tersebut, hal ini menunjukkan bahwa selama bulan tersebut jumlah narapidana selalu lebih dari daya tampung yang ada di Lapas Ngawi. Hal tersebut juga terjadi sepanjang tahun 2018, dimana setiap bulannya terdata Lapas Ngawi mengalami kelebihan daya tampung.

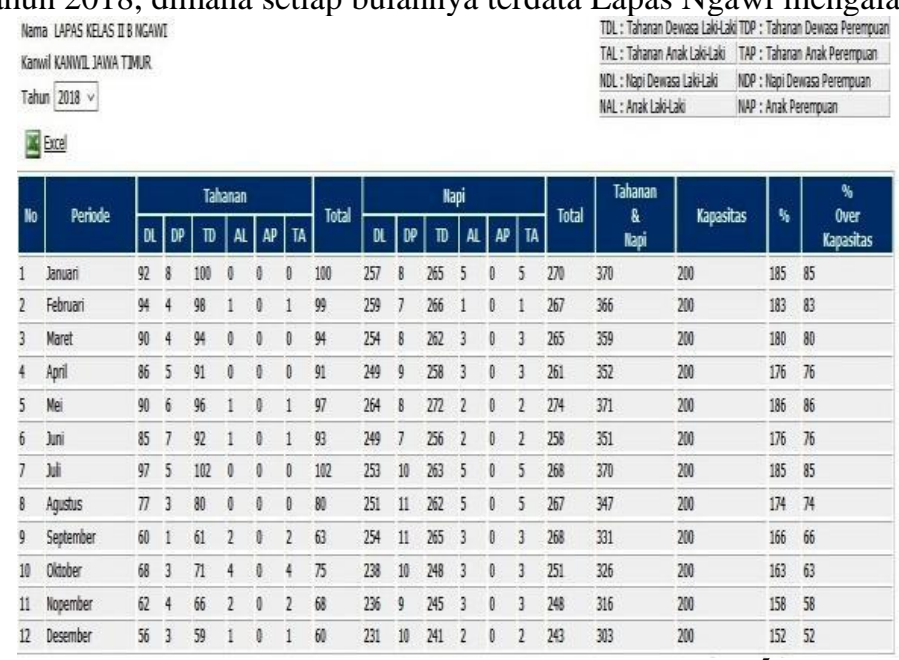

Tabel 3. Data Penghuni Lapas Ngawi pada Tahun $2018^{5}$

Kelebihan jumlah narapidana lebih dari 100 orang sepanjang tahun 2018 bisa dilihat dari tabel di atas. Terkait data kelebihan jumlah narapidana ini, pihak Lapas Ngawi secara prinsip tidak bisa mengerem atau kuasa membatasi sesuai kapasitas yang ada,

\footnotetext{
${ }^{4}$ ibib. di akses pada 9 Juli 2019 pukul 13.52 WIB

${ }^{5}$ ibib.
} 
karena diluar kewenangan yang diberikan peraturan perundang-undangan. Disisi lain, Lapas Ngawi tetap dituntut untuk memberikan layanan yang maksimal terutama yang berkaitan erat dengan hak-hak narapidana. Adapun kendala-kendala yang dihadapi pengelola Lapas Ngawi akibat kelebihan daya tampung penghuni lapas beserta solusi untuk tetap memberikan layanan terbaik dalam pemenuhan hak narapidana adalah sebagai berikut:

1. Mengisi sel kecil dengan 10 orang narapidana dan sel besar dengan 20 orang narapidana. Tentunya ini mengurangi kenyamanan narapidana, namun pihak Lapas Ngawi berupaya untuk mengkomunikasikan dengan baik kepada narapidana dan melakukan pendekatan kekeluargaan. Dari jumlah narapidana yang ada, dimanajemen dengan baik untuk tugas membersihkan kamar mandi, dengan harapan dengan kamar mandi yang bersih, bisa mengurangi ketidaknyamanan akibat kamar sel melebihi kapasitas.

2. Tingkat perselisihan antar warga binaan meningkat merupakan hal yang tidak bisa dihindarkan ketika penghuni melebihi daya tampung yang ada. Hal ini menjadi perhatian ekstra pengelola Lapas Ngawi supaya tidak terjadi perselisihan antar warga binaan. Salah satu cara yang efektif adalah dengan memaksimalkan dan memberi perhatian yang ekstra ketika disinyalir timbul perselisihan antar warga binaan. Dengan harapan permasalahan tidak menumpuk dan segera mencairkan suasana.

3. Rentan penularan beberapa jenis penyakit kulit. Hal ini disebabkan kamar sel yang tidak selonggar ketika lapas dalam keadaan tidak kelebihan standar penghuni. Dalam kasus ini, pengelola Lapas Ngawi proaktif memantau kondisi warga binaannya serta segera menangani apabila ada temuan atau pasien berpenyakit mudah menular tersebut. Harapannya adalah supaya, penyebaran penyakit tidak terjadi di Lapas Ngawi.

Dari hasil yang dicapai dalam penelitian ini, adapun potensi yang bisa digunakan untuk kelanjutan kedepannya adalah sebagai berikut:

1. Narapidana Penghuni Lapas Ngawi merupakan seseorang baik katagori dewasa atau anak-anak yang berdasar keputusan pengadilan dipidana penjara untuk kurun waktu tertentu, yang berarti sifatnya tidak tetap. Dengan adanya penelitian ini, bisa menjadi bahan referensi kondisi Lapas Ngawi saat ini untuk narapidana kedepannya.

2. Adanya temuan kelebihan penghuni Lapas Ngawi pada tahun 2018 dan paruh tahun 2019, dapat di jadikan acuan untuk penelitian selanjutnya yang lebih khusus mengkaji terkait over capacity Lapas Ngawi dari berbagai aspek.

3. Kehidupan di dalam Lapas Ngawi, berdasar peraturan perundang-perundangan memang dibatasi untuk pengunjung dari luar untuk mengakses. Hal ini bertujuan semata-mata untuk menjamin keamanan dan tujuan pemidanaan dengan sanksi penjara dapat terwujud. Dengan adanya penelitian-penelitian ilmiah secara kontinue dan berkesinambungan, akan dapat mengurangi kesenjangan informasi antara kehidupan di dalam lapas dengan yang di luar karena hasil dari penelitian ini nantinya disebarluaskan melalui mekanisme publikasi jurnal.

\section{IV.PENUTUP}

\section{A. Kesimpulan}

Upaya yang dilukan Lapas Ngawi dalam rangka pemenuhan hak-hak narapidana sudah mengacu pada ketentuan peraturan perundang-undangan yang berlaku dan Standar Operasional Pelaksanaan yang ada. Setiap narapidana berhak atas kesempatan beribadah sesuai agama dan keyakinannya, mendapat fasilitas perawatan jasmani maupun rohani, memperoleh pendidikan Kejar Paket A,B, dan C bagi yang putus sekolah serta program keterampilan berwirausaha, mendapat perawatan yang layak bagi narapidana yang sakit, hak untuk mendapat kunjungan, dan yang lainnya. Dalam upaya pemenuhan hak narapidana tersebut ditemukan adanya kendala yang dihadapi akibat kelebihan kapasitas/over capacity penghuni Lapas Ngawi. Kendala tersebut antara lain adalah menempatkan penghuni lapas dalam sel kamar kecil sejumlah 10 orang dan kamar besar diisi 20 orang, tingkat perselisihan antar warga binaan tinggi, serta mudahnya penyebaran penyakit kulit. Untuk mengatasi kendala tersebut, pihak pengelola Lapas Ngawi berupaya kerasa untuk mengatasisnya secara maksimal dengan cara menyelesaikan secepat mungkin setiap permasalahan yang ditimbulkan dari kendala tersebut.

Dengan adanya hasil penelitian ini, potensi utama ke depan adalah bisa dijadikan bahan referensi untuk penghuni lapas dimasa akan datang, sebagai acuan penelitian lanjutan dengan pengembangan tema over capacity, dan sebagai penjembatan informasi untuk mengatasi kesenjangan antara kehidupan didalam lapas dengan dunia luar.

\section{B. Saran}

1. Untuk Pengelola Lapas Ngawi diharapkan bisa mempertahanhan layanan pemenuhan hak narapidana yang sudah berjalan saat ini untuk kedepannya;

2. Untuk narapidana Lapas Ngawi di masa akan datang supaya memahami hak-hak yang bisa didapat selama menjadi warga binaan Lapas Ngawi; dan

3. Pemerintah Republik Indonesia diharapkan bisa memecahkan permasalahan over capacity yang terjadi di Lapas Ngawi, sehingga kendala dalam pemenuhan hak narapidana yang terbentur dengan masalah kelebihan kapasitas penghuni lapas tidak terjadi lagi di masa akan dating. 
Website : http://yustisia.unmermadiun.ac.id/index.php/yustisia

\section{DAFTAR PUSTAKA}

Fatimah, dkk., 2015, Implementasi Kebijakan Perlindungan Hukum Terhadap Hak-Hak Narapidana Di Rutan Kelas IIB Kuala Kapuas KAL-TENG, Jurnal Pendidikan Kewarganegaraan, Volume 5, Nomor 9.

Heningtias Gahas Rukmana, 2014, Hak-Hak Narapidana Wanita di Lembaga Pemasyarakatan Kelas II A Yogyakarta, Skripsi, Fakultas Syariah dan Hukum Universitas Islam Negeri Sunan Kalijaga Yogyakarta.

Peter Mahmud Marzuki, 2010, Penelitian Hukum, Kencana, Jakarta, cetakan ke-6.

Soerjono Soekanto, 1985, Penelitian Hukum Normatif, RajawaliPers, Jakarta.

Undang-Undang Nomor 12 Tahun 1995 tentang Pemasyarakatan (Lembar Negara Tahun 1981 Nomor 76, Tambahan Lembar Negara Nomor 3641)

Vahronia Ardiyanta, dkk, 2017, Implementasi Pemenuhan Hak - Hak Narapidana di Rumah Tahanan Kelas II B Kabupaten Blora Menurut Undang - Undang Nomor 12 Tahun 1995 Tentang Pemasyarakatan”, Diponegoro Law Journal, Volume 6, Nomor 1. 